\title{
SEGMENTASI PARU-PARU PADA CITRA X-RAY THORAX MENGGUNAKAN DISTANCE REGULARIZED LEVELSET EVOLUTION (DRLSE)
}

\author{
Mokhamad Amin Hariyadi
}

\begin{abstract}
Lung is one in control in the circulatory system of air (oxygen) in the human body, so the detection of disorders of the human respiratory urgently needed to detect any disturbance in the lungs used X-ray beam, from the results of $\mathrm{x}$-ray image of the thorax contained information used to analyze and determine the shape of an object from the lungs, in order to obtain such information, a process of segmentation. In this study used methods Distance regularized Levelset Evolution (DLRSE), this method region based models which is an improvement of edge-based models. The purpose of this study to implement segmentation methods DRLSE the lungs of the results of $x$-ray image of the thorax. The trial results with the system DLRSE method performed on the 20 data from X-ray image of the thorax obtained an average result accuracy of $87.90 \%$, a sensitivity of $76.27 \%$ and a specificity of $93.98 \%$.
\end{abstract}

Keyword : DRLSE, Lung, X-ray

Abstrak-Paru-paru merupakan salah satu pemegang kendali dalam sistem perdaran udara (oksigen) dalam tubuh manusia, sehingga deteksi terhadap gangguan pernapasan manusia sangat dibutuhkan, untuk mendeteksi adanya gangguan pada paru digunakan sinar $\mathrm{X}$-ray, dari hasil citra $x$-ray thorax terdapat informasi yang digunakan untuk menganalisa dan mengetahui bentuk suatu objek dari paru-paru, guna memperoleh informasi tersebut, dilakukan proses segmentasi. Pada penelitian ini digunakan metode Distance regularized LevelSet Evolution (DLRSE), metode ini region based model yang merupakan perbaikan dari edge based model. Tujuan penelitian ini untuk mengimplementasikan metode DRLSE pada segmentasi paru-paru dari hasil citra $x$-ray thorax. Hasil uji coba sistem dengan metode DLRSE yang dilakukan pada 20 data hasil citra $X$-ray thorax didapatkan rata-rata hasil

Manuscript received February 22, 2017. This work was supported in part by Informatics Engineering Department of Maulana Malik Ibrahim Islamic State University.

Mokhamad Amin Hariyadi is with the Informatic Engineering Departement of Maulana Malik Ibrahim Islamic State University , Malang; email adyt2002@yahoo.com) akurasi $87.90 \%$, sensitifitas $76.27 \%$ dan spesifisitas $93.98 \%$.

Kata Kunci : DRLSE, Paru, $X$-ray

\section{PENDAHULUAN}

Daru-paru adalah organ dalam manusia yang berfungsi menukar $\mathrm{O}_{2}$ dari udara dengan $\mathrm{CO}_{2}$ dari darah dengan bantuan hemoglobin. Proses tersebut dikenal sebagai respirasi. Paru-paru terletak didalam rongga dada (thorax), dilindungi oleh struktur tulang selangka dan diliputi dua dinding yang disebut pleura, kedua lapisan tersebut dipisahkan oleh lapisan udara yang di kenal sebagai rongga plueral yang berisi cairan pleural[1].

Pengolahan hasil citra $x$-ray thorax di butuhkan proses komputerisasi agar diperoleh hasil yang lebih akurat, selain itu lebih memudahkan pengguna (ahli medis) dalam membaca hasil citra $x$-ray thorax.

Dalam perkembangan teknologi image processing $x$-ray thorax hingga saat ini terus diperluas dengan tujuan untuk membantu manusia dalam melakukan pekerjaan. Image processing merupakan salah satu jenis teknologi untuk menyelesaikan masalah mengenai pemrosesan gambar, dalam image processing $x$-ray thorax gambar yang ada diolah sedemikian rupa sehingga gambar tersebut lebih mudah untuk di proses[2].

Segmentasi merupakan langkah pertama dan menjadi bagian penting dalam pengenalan objek (object recognition). Segmentasi merupakan teknik untuk membagi citra menjadi beberapa daerah (region) pada setiap daerah memiliki kemiripan atribut antara lain: tingkat keabuan (grayscale), tekstur (texture), warna (color), dan gerakan (motion) [3].

Penelitian ini bertujuan membangun aplikasi untuk membantu kinerja para tenaga medis khususnya, agar dapat membantu dalam proses membaca hasil citra $x$-ray, dengan menggunakan metode Distance Regularized Level Set Evolusion (DRLSE). DRLSE merupakan pengembangan dari metode segmentasi Level Set. Metode DRLSE tidak membutuhkan reinitialization jadi waktu komputasi dapat lebih cepat 
daripada metode Level Set. Tetapi jika gambar medis memiliki ukuran yang besar, maka waktu yang di butuhkan untuk komputasi lebih lama.

\section{DATA}

Data berupa hasil $X$-ray thorax yang diperoleh dari citra medis (medical image), merupakan cara yang digunakan untuk mendapat gambar manusia secara lengkap atau bagian-bagian beserta fungsinya untuk tujuan klinis, melalui prosedur medis guna mengungkap keadaan anatomi dan fisiologi tubuh, mendiagnosis atau memeriksa penyakit. Berbagai metode yang digunakan dalam pencitraan (scanning) tubuh manusia antara lain : radiologi kedokteran, endoskopi, Thermography, fotografi medis dan mikroskopi (misalnya untuk penyelidikan patologis manusia). Pengukuran dan teknik perekaman dirancang untuk menghasilkan gambar, seperti electro encephalography (EEG), magneto encephalography (MEG), electro cardiography (EEG), yang menghasilkan data rentang (scala) dalam bentuk dua atau tiga dimensi (berisi informasi posisi), yapat dilihat sebagai bentuk pencitraan medis[4].

Manfaat $X$-ray dalam ilmu kedoteran, yaitu $x$-ray dapat digunakan untuk melihat kondisi tulang, gigi, paru-paru serta organ tubuh yang lain tanpa melakukan pembedahan langsung pada tubuh pasien. Selain bermanfaat, $x$-ray mempunyai efek atau dampak yang sangat berbahaya bagi tubuh, yaitu apabila digunakan berlebihan akan menimbulkan penyakit yang berbahaya, misalnya kanker. Oleh sebab itu, para dokter tidak menganjurkan terlalu sering memakai "foto rontgen" secara berlebihan[5].

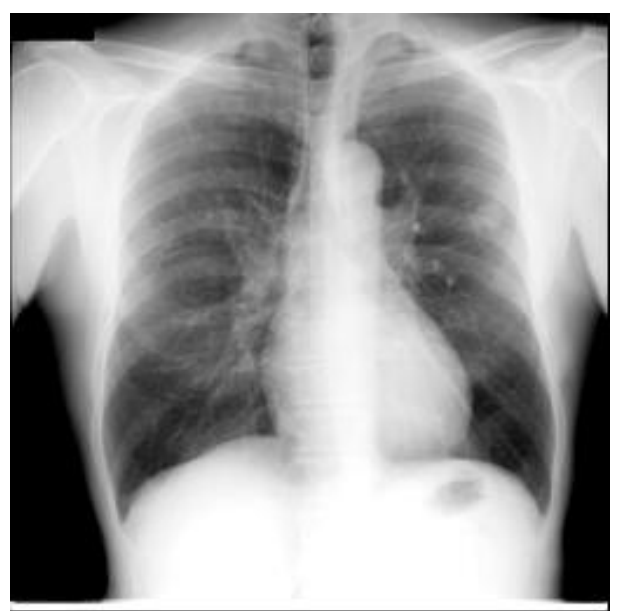

Gambar 2.1. Gambar citra X-Ray Thorax[6]

\section{METODE PENELITIAN}

Metode yang diusulkan dalam penelitian ini dapat dilihat pada Gambar 3.1. Metodologi yang digunakan meliputi praprosessing citra, segmentasi citra, verifikasi hasil.

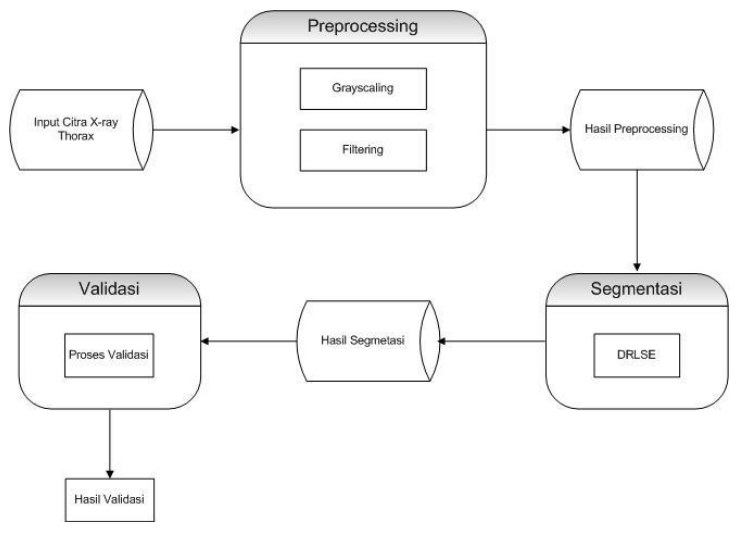

Gambar 3.1. Blok diagram Sistem

\section{A. Preprocessing (Proses Awal)}

Preprocessing bertujuan untuk meningkatkan kualitas citra input sebelum digunakan pada proses segmentasi citra, pada tahap preprocessing citra input diproses terlebih dahulu menjadi citra grayscale, kemudian dilakukan filtering, agar diperoleh data inputan citra $x$-ray dengan kontras yang baik[7], sehingga memberikan hasil yang lebih baik ketika dilakukan segmentasi dengan metode Distance Regularized Level Set Evolution (DRLSE). Tahapan preprocessing yang digunakan sebagai berikut:

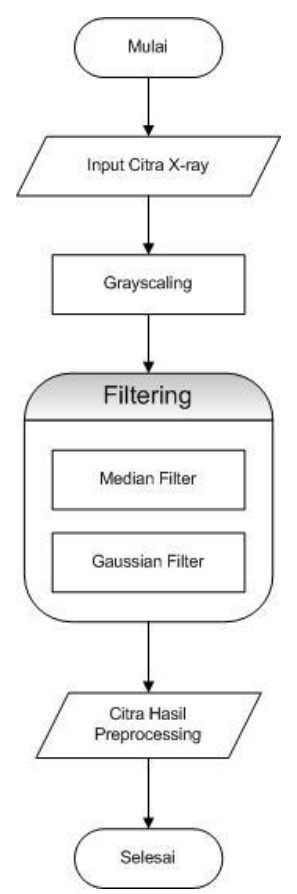

Gambar 3.2. Diagram Alir Proses Preprocessing

\section{B. Proses Segmentasi}

Desain segmentasi menggunakan metode Distance Regularized Level Set Evolution (DRLSE) yang akan digunakan sebagai berikut : 


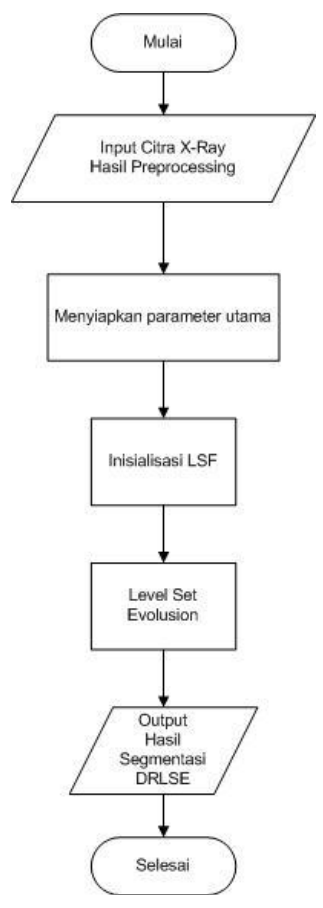

Gambar 3.3. Diagram Alir Proses Segmentasi DRLSE[8]

Segmentasi ini diawali dengan menentukan parameter utama diantaranya menentukan banyaknya iterasi, kecepatan dalam evolusi, lambda, serta panjang jarak regulasi, setelah menentukan parameter utama tersebut, dilakukan proses inisialisasi LSF yang bertujuan untuk menentukan titik awal LSF pergerakan evolusi dari fungsi DRLSE, kemudian proses selanjutnya adalah proses pergerakan evolusi dari Level Set [9]. Pada proses DRLSE, penentuan parameter banyaknya iterasi dan kecepatan evolusi sangat berpengaruh pada hasil segmentasi gambar.

DRLSE merupakan pengembangan metode Level Set, dengan rumus DRLSE[10].

$$
\frac{\partial \phi}{\partial t}=\mu \operatorname{div}(\operatorname{dp}(\nabla \phi) \nabla \phi+F|\nabla \phi|+A . \nabla \phi
$$

Rumus tersebut menunjukkan skema numerik stabil tanpa memerlukan re-initialisasi. DRLSE dapat digunakan untuk segmentasi citra yang mencakup basis wilayah atau pembentukan citra yang berbasis tepi.

Algoritma pertama menyaring citra menggunakan filter Gaussian Kernel untuk menghaluskan dan menghilangkan derau pada citra, dengan perhitungan fungsi daya:

$$
\varepsilon(\phi)=\mu R_{p} \phi+\lambda \mathcal{L}_{g}(\phi)+\alpha A_{g}(\phi)
$$

dimana $R_{p}$ adalah regularisasi level set, $\lambda>0$ dan $\alpha \in$ R koefisien fungsi daya, $\mathcal{L}_{g}(\phi)$ dan $A_{g}(\phi)$.

$$
R_{p}(\varnothing) \triangleq \int \Omega p(|\nabla \phi|) d x
$$

dimana $\mathrm{P}$ adalah potensial energy

$$
\begin{aligned}
& \mathcal{L}_{g}(\varnothing) \triangleq \int \Omega g \delta(\phi)(|\nabla \phi|) d x \\
& A_{g}(\varnothing) \triangleq \int \Omega g H(-\phi) d x
\end{aligned}
$$

$A_{g}$ adalah kecepatan dari fungsi akselerasi level set. $\mathcal{L}_{g}$ adalah tingkat minimum saat menetukan bata fungsi objek.

\section{Validasi}

Validasi dilakukan dengan membandingkan hasil segmentasi dari hasil penelitian dengan hasil segmentasi manual (radiolog). Validasi menyatakan kemungkinan terjadinya kesalahan atau kebenaran pencocokan pada sistem. Langkah awal dari validasi adalah dicari nilai TP, FP, TN dan FN, setelah nilai ditemukan maka nilai akan dimasukkan ke dalam rumus akurasi, sensitifitas dan spesifisitas Flowchart dari validasi ini dapat dilihat pada Gambar 3.4.

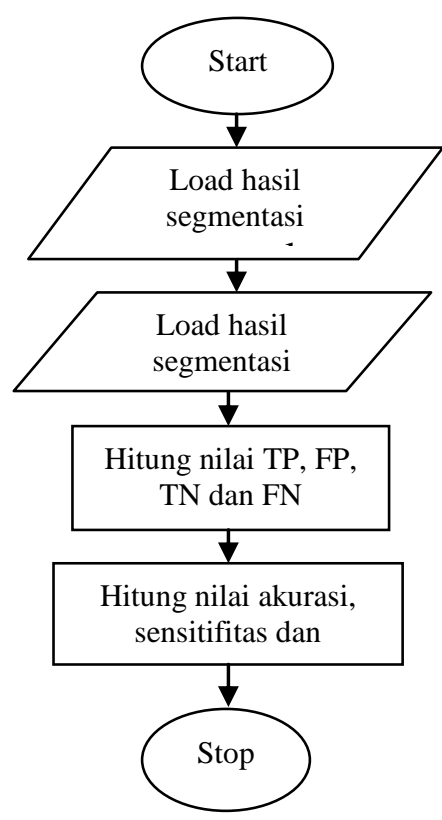

Gambar 3.4. Flowchart proses validasi

Langkah pertama dari metode DLRSE yaitu, inisialisasi awal atau inisialisasi model awal. Inisialisasi awal dilakukan dengan ditentukan nya letak dari masking secara terprogram. Kemudian masking mengalami pergerakan. Pergerakan di dalam penelitian ini bergerak mengembang, karena inisialisasi awal berada di dalam atau lebih kecil dari objek paru-paru. Parameter yang digunakan dalam penelitian ini menggunakan parameter yang telah ditentukan yaitu, $\alpha=.2$ Gambar 4.1 adalah contoh hasil uji coba segmentasi paru-paru dengan menggunakan metode DLRSE

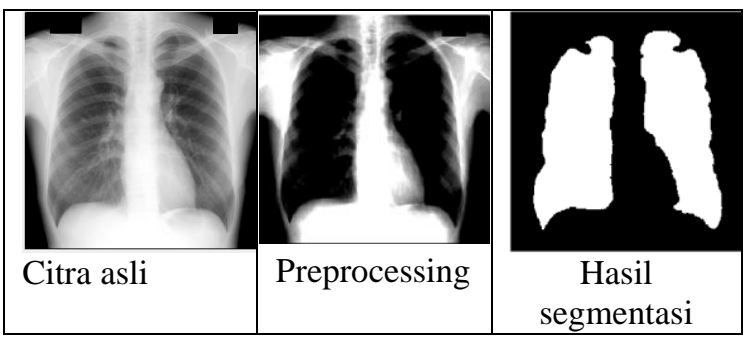

Gambar 4.1 Contoh hasil uji coba segmentasi paru-paru 
Citra hasil segmentasi metode DLRSE dibandingkan dengan citra hasil segmentasi manual untuk mengetahui nilai ketepatan dan ketidak tepatan dari kedua citra tersebut. Pengujian ini menggunakan data input sebanyak 20 citra, diperoleh hasil validasi berupa nilai akurasi, sensitifitas dan spesifisitas, ditunjukkan pada tabel 4.1.

Tabel 4.1 Hasil Perhitungan Perbandingan Citra Hasil segmentasi paru-paru

\begin{tabular}{|c|c|c|c|c|}
\hline No & Nama citra & $\begin{array}{c}\text { Akurasi } \\
(\%)\end{array}$ & $\begin{array}{c}\text { Sensitifitas } \\
(\%)\end{array}$ & $\begin{array}{c}\text { Spesifitas } \\
(\%)\end{array}$ \\
\hline 1 & JPCLN001 & 84.79 & 74.47 & 90.79 \\
\hline 2 & JPCLN007 & 82.04 & 71.76 & 88.38 \\
\hline 3 & JPCLN008 & 89.99 & 83.12 & 94.69 \\
\hline 4 & JPCLN018 & 85.43 & 76.48 & 94.62 \\
\hline 5 & JPCLN021 & 85.78 & 77.36 & 90.88 \\
\hline 6 & JPCLN023 & 89.67 & 79.98 & 94.81 \\
\hline 7 & JPCLN035 & 88.14 & 82.18 & 91.95 \\
\hline 8 & JPCLN043 & 91.05 & 81.31 & 95.37 \\
\hline 9 & JPCLN045 & 87.26 & 82.55 & 90.38 \\
\hline 10 & JPCLN049 & 86.45 & 81.10 & 89.73 \\
\hline 11 & JPCLN005 & 82.64 & 70.04 & 88.72 \\
\hline 12 & JPCLN009 & 84.03 & 71.07 & 91.28 \\
\hline 13 & JPCLN024 & 91.96 & 76.27 & 98.71 \\
\hline 14 & JPCLN025 & 90.61 & 76.08 & 96.39 \\
\hline 15 & JPCLN030 & 86.94 & 72.41 & 93.89 \\
\hline 16 & JPCLN031 & 91.16 & 78.15 & 97.56 \\
\hline 17 & JPCLN033 & 90.54 & 74.19 & 97.89 \\
\hline 18 & JPCLN038 & 92.05 & 79.06 & 97.16 \\
\hline 19 & JPCLN039 & 89.33 & 69.58 & 98.23 \\
\hline 20 & JPCLN062 & 88.09 & 68.31 & 98.17 \\
\hline \multicolumn{2}{|c|}{ RATA-RATA } & 87.90 & 76.27 & 93.98 \\
\hline
\end{tabular}

Berdasarkan Tabel 4.1 menunjukkan metode

DLRSE dapat digunakan untuk mensegmentasi paruparu, dengan rata-rata perbandingan dari hasil segmentasi paru-paru yaitu, akurasi $87.90 \%$, sensitifitas $76.27 \%$ dan spesifisitas $93.98 \%$. Segmentasi paru-paru akurasi tertinggi terdapat pada gambar JPCLN038, dengan akurasi sebesar 92.05 , terendah pada gambar JPCLN007 akurasi sebesar 82.04. Sensitifitas tertinggi terdapat pada gambar JPCLN008, dengan nilai 83.12, dan terendah pada gambar JPCLN062 dengan nilai 68.31. Spesifitas tertinggi pada gambar JPCLN024 dengan nilai $98.71 \%$ dan terendah pada gambar JPCLN007 sebesar $88.38 \%$.

\section{KESIMPULAN DAN SARAN}

Segmentasi kontur paru pada hasil citra $X$-Ray Thorax menggunakan metode DLRSE dapat digunakan untuk mensegmentasi objek paru-paru, hal ini dibuktikan dengan hasil rata-rata hasil akurasi $87.90 \%$, sensitifitas $76.27 \%$ dan spesifisitas $93.98 \%$. Hasil tersebut menunjukkan metode ini dapat digunakan sebagai alternatif dalam membaca hasil citra $x$-ray thorax.

Penelitian ini terdapat beberapa kekurangan yang ditunjukkan dengan besarnya selisih akurasi rata-rata dan akurasi terendah, sehingga dapat digunakan menjadi acuan dalam pengembangan penelitian di masa yang akan datang.

\section{REFERENSI}

[1] Fatchoerochman, Zulqarnain, N., Kuntjoro, E., 2010, Insidens Pneumonitis Radiasi pada Penderita Karsinoma Payudara yang Mendapat Terapi Kemoradiasi di RSSUP Dr. Kariadi, Bagian Radiologi FK UNDIP, RSUP Dr. Kariadi Semarang,

[2] Rasad, S., 2005, Radiologi Diagnostik Edisi Kedua, Balai Penerbit FKUI, Jakarta.

[3] Gonzalez, R.C., dan Woods, R.E., 2008,Digital Image Processing Third Edition, Prentice-Hall, Inc., New Jersey.

[4] Gabriel, J. F., 1996, Fisika Kedokteran, Penerbit Buku Kedokteran, EGC: Jakarta.

[5] Gabriel S ${ }^{1}$, Lau RW, Gabriel C., 1996. The dielectricproperties of biological tissues: III. Parametric models for the dielectric spectrum of tissues. Physics Department, King's College, Strand, London, UK. Phys Med Biol. 1996 Nov;41(11):2271-93.

[6] Image Sciences Institute Research Databases.http://www.isi.uu.nl/Research/Database s/SCR/ 